\title{
Teaching Ethics and Values: A Survey of Graduate Public Affairs and Administration Programs in the U.S.*
}

\author{
Donald C. Menzel, University of South Florida
}

\section{Introduction}

Moral education once occupied a central place in the intellectual life of students and professors. As Derek Bok reminds us in Universities and the Future of America, professors and college presidents committed themselves to strengthening the character of their students thereby contributing to "an educated class committed to a principled life in the service of society" $(1990,66)$. By World War II, moral education on America's campuses had largely given way to the competing claims of Darwinism, Marxism, and science. The decades following World War II witnessed the spectacular growth and eventual dominance of "big" science and its stepchild, technology. The social sciences, including political science, pursued the holy grail of science with fierce determination, if not reckless abandon. While moral and even civic education had largely vanished from the campus, even more troubling to some was that colleges and universities had yielded their status and claim as an important source of moral guidance for society (Bok 1990, 68).

America's moral compass began to swing even more erratically in the aftermath of Vietnam, Watergate, the near impeachment and removal of a sitting President, the arms race, the Iran-Contra affair, and Wall Street-HUD-Capitol Hill scandals of the 1980s. "Moral drift," as it might be called, has contributed to the steady erosion of public confidence in government, a widening chasm of distrust between citizen and public official, and in light of the Oklahoma City bombing tragedy, perhaps even fostered outright rejection of constitutional authority. Complicating matters, young men and women no longer view working for or in government as an attractive career (Thompson 1993). These conditions and other value-laden issues (e.g., abortion, right to die, gay rights, comparable worth) have resulted in a renewed interest in and commitment to incorporating values into the college curriculum. The "what," "how," and "who" questions involved in this undertaking are, of course, challenging and even daunting. Nonetheless, colleges and universities have moved forward with courses and programs aimed at insuring that we do not produce "a new generation of leaders who are ethically illiterate at best or dangerously adrift and morally misguided at worst," as was stated bluntly in a recent Hastings Center report (Jennings, Nelson, and Parens 1994, 2).

Bok labels this effort as the "new" ethics. As he puts it, today's applied ethics course "does not seek to convey a set of moral truths but tries to encourage students to think carefully about complex moral issues" (1990, 73). Furthermore, he asserts, "the principal aim of the course is not to impart 'right answers' but to make students more perceptive in detecting ethical problems when they arise, better acquainted with the best moral thought that has accumulated through the ages, and more equipped to reason about the ethical issues they will face in their own personal and professional lives" $(1990,73)$.

\section{Purpose of this Paper}

This paper examines efforts made in recent years to introduce the "new" ethics into the curriculums of graduate studies programs in public affairs and administration (PA/A) in the United States. Teaching what some contend "can't be taught"ethics and values-is energetically underway in the 1990s. Although not without arguable issues (see Lee 1990; Worthley and Grumet 1983), the list of PA/A schools offering ethics courses or ethics-across-the-curriculum grows longer each year. This paper builds on a series of previous studies conducted since 1970 that attempt to track the teaching of ethics at PA/A schools. Among other questions, these studies have sought answers to the following:

- "Why has ethics education become important?" (Rohr 1976; Dwivedi and Engelbert 1981)

- "What factors influence decisions to offer ethics courses?" (Lee and Pugh 1987; Lee 1990)

- "What are or should be the goals of ethics education?" (Fleishman and Payne 1980; Hejka-Ekins 1988)

- "How does or should a program/ department incorporate ethics instruction into the curriculum?" (Bowman and Menzel, 1997; Catron and Denhardt 1994)

- "What is/should be the content of ethics courses?" (Catron and Denhardt 1988)

- "How do faculty respond to ethics pedagogy?" (Piper, Gentile, and Parks 1993)

Other important, yet seldom studied questions include:

- "What instructional methodologies are employed to teach ethics?"

- "Who actually teaches ethics courses?"

And, of course, probably the most important, yet least investigated question:

- "What difference does ethics education make in the life and behavior of men and women in pursuit of public service careers?"

\section{Research Questions}

The findings reported in this paper provide additional perspective on several of the questions raised above, but goes further by addressing the following questions:

- Are there any patterns in the growth of ethics instruction provided by PA/A programs? 


\section{FIGURE 1}

Cumulative \# of Programs Adopting an Ethics Course $(\mathrm{n}=62)$

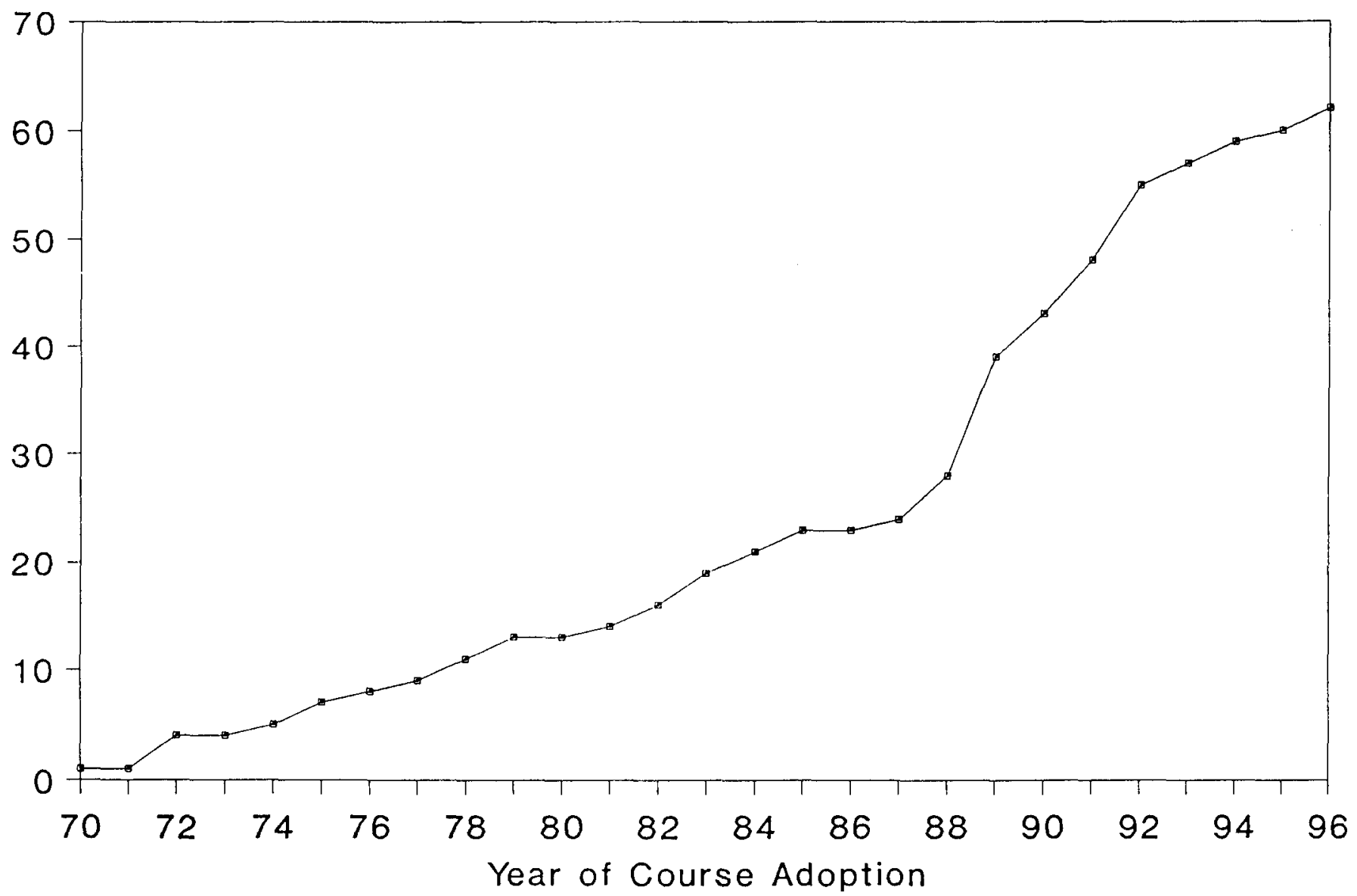

- Why have some schools moved more quickly than others in adopting ethics courses?

- What are the primary goals of ethics education in PA/A programs?

- What are the primary conceptual approaches in ethics instruction?

- What are the most commonly used instructional methods and technologies employed in PA/A ethics instruction?

- What are the apparent outcomes of ethics education? Does ethics instruction seem to make a difference?

\section{Study Methodology}

In the spring of 1995, I developed a survey questionnaire to solicit answers to the questions above. The target population consisted of 229 member schools of the National Association of Schools of Public Affairs and Administration (NASPAA), the accrediting body for academic programs in public affairs and administration. Among the 229 NASPAA schools, 225 offer a professional master's degree in public administration, public affairs, public policy, or some combination thereof. And, as of July 1995, 124 member schools had NASPAA accredited programs of study.

Each member school has a NASPAA Principal Representative (PR), typically the program director or coordinator. This person serves as the liaison between the program faculty and NASPAA and attends NASPAA's annual conference each autumn. A questionnaire was mailed to all PRs along with a postage paid return addressed envelope. The cover letter informed the PR of the objectives of the research and suggested that he/she complete the questionnaire and/or solicit input from knowledgeable faculty for those sections of the questionnaire that the PR may not have sufficient information. A follow up letter and questionnaire were mailed to non-respondents in May 1995. A total of 138 schools responded, with 134 returning usable questionnaires for a response rate of $60 \% .{ }^{1}$

A NASPAA data base was also drawn upon and integrated with the survey data base for the analysis that follows. NASPAA compiles program data every two years dealing with size of program, number of graduates, number of faculty, etc. This data base, which was collected in 1992 and published in the $1994 \mathrm{Di}$ rectory of Programs, was used.

\section{Teaching Ethics: Where, Why, and Who?}

Nearly $60 \%(n=78)$ of the respondents $(n=134)$ indicated that 
their graduate program offers an ethics course. A smaller percentage- $40 \%$ - said that they teach "ethics across the curriculum." Teaching ethics across the curriculum can be done (a) formally or informally and (b) either with or without an ethics course. If a respondent indicated that his/her program taught ethics across the curriculum, then he/she was asked to describe the program. Most said they do not have a formal program but, as one person described the informal approach taken in his program said: "each course addresses ethical issues within the context of the materials." Another replied more tentatively: "I hope we teach ethics across the curriculum, but it is not emphasized as a formal program thrust."

Do programs that offer an identifiable ethics course require MPA degree seeking students to take the course? The answer is "no," at least for the majority of programs. Only one of every four programs requires a student to complete an ethics course to receive the MPA. Still, the development and adoption of ethics courses has grown steadily over the past 25 years (see Figure 1). Figure 1 also shows a sharp jump in the number of courses adopted in 1989 and after. This was probably due to the adoption of a new NASPAA curriculum standard (3.21) that went into effect that year which states: "The common curriculum components shall enhance the student's values, knowledge, and skills to act ethically."

\section{Why Adopt an Ethics Course?}

The growth in the adoption of ethics courses raises several questions. For instance, why have some schools embraced ethics instruction by developing an ethics course while others have not? Also, why have some schools moved more quickly than other schools in adopting ethics courses? Are there discernable patterns of adoption? Is there a diffusion effect? Does size make a difference? Are larger schools more likely than smaller schools to offer ethics instruction? Does structure make a difference? Are PA/A programs housed in PA/A departments or pro- fessional schools more likely to emphasize ethics instruction than PA/A programs housed in departments of political science? Does accreditation make a difference? Are schools that have been accredited for a longer period more likely to emphasize ethics education than are non-accredited schools or schools that have been accredited for a short period of time?

\section{Program Size and Ethics Instruction.} What might be concluded about size? As measured by the number of MPA degrees awarded, size is associated with whether or not a school offers an ethics course. Larger programs, as Table 1 shows, are more likely to have an ethics course in their curriculum than smaller programs. Approximately one of every two smaller programs-those awarding 20 or fewer MPA degrees-offer an ethics course. In contrast, nearly three of every four larger programs offer an ethics course. A similar relationship does not hold, however, when one investigates the matter of requiring students to take an ethics course. While $31 \%$ of the larger programs compared to $20 \%$ of the smaller programs require MPA students to take an ethics course, the difference is not statistically significant.

\section{Organizational Structure and Ethics} Instruction. Turning next to organizational structure, what might be concluded? Among the 134 study programs, 106 could be clearly classified as belonging to one of three NASPAA categories: (1) a separate professional school of PA/A $(\mathbf{n}=17)$ that reports directly to central university administration in the same or similar manner as a law school; (2) a separate department or center $(\mathbf{n}=$ 44) of PA/A in a larger unit such as a social science division or college of arts and sciences; or (3) a PA/A program $(n=45)$ within a political science department. Cross tabular analysis of organizational structure using these categories with incorporation/ non-incorporation of an ethics course in the MPA program of study as the dependent variable resulted in a statistical finding of no significance at the .05 level of probability. However, the percentages do show that $71 \%$ of the professional schools of
PA/A offer an ethics course compared to $59 \%$ for PA/A departments, and $53 \%$ for political science housed programs. As far as "requiring" the completion of an ethics course for the MPA degree, the percentages are quite similar for all three categories of organizational structure with nearly three of every four respondents in each categories reporting they do not require MPA students to complete an ethics course.

Accreditation and Ethics Instruction. Does NASPAA accreditation motivate programs to adopt an ethics course? In brief, "no." Whether a PA/A program is or is not accredited makes little difference statistically in whether a unit offers an ethics course or requires MPA students to complete such a course for graduation. Among the 134 study respondents, 78 were accredited and 56 were not. Majorities in each category (63\% for the accredited group and $52 \%$ of the non-accredited group) said their program offered an ethics course. These differences are not statistically significant. Similar findings can be reported for requiring MPA candidates to take an ethics course.

Also investigated was whether or not schools that were early adopters of an ethics course were also schools that had been accredited earlier than other schools. In other words, is there any relationship between the speediness of seeking accreditation and the speediness of adopting an ethics course? The answer is "no". There is no relationship between when a program received accreditation and when the decision was made to adopt an ethics course.

These findings point to two conclusions. First, the decision to add an ethics course to the MPA curriculum appears to be highly localized. That is, adding an ethics course is most likely to be the result of (a) one or more faculty members' interests, (b) specific program needs, and/or (c) the culture of the particular academic environment. Second, insofar as localized influences are mitigated, it is probably the result of program size with attendant curriculum differentiation. A larger faculty in conjunction with a larger student 
TABLE 1.

Size of Program and Ethics Course Offerings

\begin{tabular}{|c|c|c|c|}
\hline & & \multicolumn{2}{|c|}{$\begin{array}{c}\text { MPA Degrees Awarded in } \\
1992^{\star}\end{array}$} \\
\hline & & $\begin{array}{c}1-20 \\
(n=62) \\
\%\end{array}$ & $\begin{array}{c}21 \text { or more } \\
(n=61) \\
\%\end{array}$ \\
\hline Ethics Course & $\begin{array}{l}\text { Not Offered } \\
\text { Offered }\end{array}$ & $\begin{array}{l}50 \\
50 \\
x=6\end{array}$ & $p=\begin{array}{r}28 \\
72 \\
.01\end{array}$ \\
\hline Ethics Course & $\begin{array}{l}\text { Not Required } \\
\text { Required }\end{array}$ & $\begin{array}{l}80 \\
20 \\
x=1\end{array}$ & $p=\begin{array}{r}69 \\
31 \\
p=.19\end{array}$ \\
\hline
\end{tabular}

'This division was based on the medium size of 222 MPA granting programs as reported in the 1994 NASPAA Directory of Programs. body are typically the ingredients for course and curriculum differentiation.

\section{Who Teaches Ethics Courses?}

The survey results show that ethics courses are taught mostly by fulltime PA/A faculty members, although a large number $(47 \%)$ of part-time instructors are involved in teaching ethics courses. And among those respondents $(n=60)$ who said they were the primary person in their department who provides ethics instruction, most were tenured, white $(95 \%)$, male $(73 \%)$, full professors $(57 \%)$ who had practitioner experience $(70 \%)$. Moreover, they report holding, on average, memberships in 2-3 professional associations and are very familiar with the code of ethics published by the American Society for Public Administration. Fifty-five of the 60 ethics instructors scored their familiarity with ASPA's code as either a 4 or 5 on a five point scale, with 5 representing "very familiar."

\section{Goals of Ethics Education}

Table 2 identifies more than a dozen goals of ethics education. It also shows the importance that the study respondents attach to each goal using a seven point scale, with 1 representing "little importance" and 7 representing "extreme impor- tance." The most important goals are ethical awareness, attitudes, knowledge, and behavior, although respondents who say they are the primary person who teaches ethics in their program place ethical knowledge lower on the list. Instead, they indicate that building analytical skills in ethical decision-making is among the top four goals of ethics education. Ranked lowest but certainly not regarded as "unimportant" are such goals as defining the public interest, acquiring knowledge of ethical codes, and becoming familiar with Western traditions in moral philosophy and political thought. Cultivating moral character also received lower scores. This rank order is consistent with that reported by Hejka-Ekins (1988) nearly a decade ago. Perhaps most importantly it should be noted that none of the goals listed in Table 2 received scores below the midscale value of four. In other words, while there are differences in "importance" attached to ethics educational goals, the variation is not large.

\section{Conceptual Approaches}

What are the predominant conceptual approaches taken to PA/A ethics education? The responses reported in Table 3 indicate that "moral reasoning" receives the greatest emphasis, followed closely by "democratic thought" and "citi- zenship." Approaches emphasizing "covenants" and "principles," "virtue and character development," "constitutional regime values," and "professional codes of conduct" are in the middle emphasis range. These findings suggest that NASPAA schools and ethics instructors are in less agreement about the conceptual approaches taken to ethics education than they are about the goals of ethics education.

Even more divergence is reflected by the survey respondents assessments of the instructional methods and techniques used in ethics instruction. This is evidenced in Table 4. Small group discussion, case studies, decision making scenarios, and research papers are the most frequently mentioned instructional methods used in ethics education. ${ }^{2}$ At the opposite end are PC multimedia material, field studies, biographies, and fiction. The middle range includes lectures, role playing, selfassessments, videos, guest speakers, and simulations. The average scores varied from a high of 6.00 for small group discussion to a low of 1.91 for PC multimedia materials, suggesting considerable diversity. The rare use of PC multimedia probably reflects the newness of this technology rather than its value as a pedagogical tool. Indeed, PC multimedia material as well as World Wide Webbased instructional technologies may well be rapidly incorporated into ethics courses over the next five years. Some professional associations, the International City/County Management Association, for example, have developed CD-ROM ethics materials that are currently in use in some graduate courses.

\section{Consequences of Ethics Instruction}

Respondents were asked about how ethics instruction in their programs affects students. The responses are suggestive and may be summarized as follows. Seven out of ten said that students find the subject matter valuable. Nearly all felt students are not threatened by ethics instruction. Two-thirds believe students become more ethically sensitive, although not necessarily more 


\section{TABLE 2.}

\section{Importance of Goals of Ethics Education \\ Rank Ordered by Average Scores}

\begin{tabular}{|c|c|c|}
\hline & $\begin{array}{l}\text { All } \\
\text { Respondents } \\
(n=129)\end{array}$ & $\begin{array}{l}\text { Ethics } \\
\text { Instructors } \\
(n=58)\end{array}$ \\
\hline $\begin{array}{l}\text { *Foster ethical conduct in the public } \\
\text { service }\end{array}$ & $6.45(1)$ & $6.47(2)$ \\
\hline $\begin{array}{l}\text { *Develop an awareness of ethical issues } \\
\text { and problems within the field }\end{array}$ & $6.40(2)$ & $6.48(1)$ \\
\hline $\begin{array}{l}{ }^{*} \text { Cultivate an attitude of moral obligation } \\
\text { and personal responsibility in pursuing a } \\
\text { career in the public service }\end{array}$ & $6.12(3)$ & $6.15(4)$ \\
\hline $\begin{array}{l}{ }^{*} \text { Gain knowledge of ethical standards of } \\
\text { public administration }\end{array}$ & $5.95(4)$ & $5.71(9)$ \\
\hline $\begin{array}{l}{ }^{*} \text { Build analytical skills in ethical decision } \\
\text { making }\end{array}$ & $5.84(5)$ & $6.16(3)$ \\
\hline Enable one to resolve ethical dilemmas & $5.82(6)$ & $5.83(7)$ \\
\hline Maintain the integrity of the profession & $5.67(7)$ & $5.73(8)$ \\
\hline $\begin{array}{l}\text { *Recognize the discretionary power of the } \\
\text { administrator's role }\end{array}$ & $5.60(8)$ & $5.85(6)$ \\
\hline *Stimulate the moral imagination & $5.50(9)$ & $5.9(5)$ \\
\hline Reduce racial, gender, or ethnic prejudice & $5.02(10)$ & $4.97(11)$ \\
\hline Prevent or minimize illegal behavior & $4.98(11)$ & $4.81(13)$ \\
\hline Better define the public interest & $4.97(12)$ & $5.07(10)$ \\
\hline${ }^{*}$ Cultivate moral character & $4.91(13)$ & $4.95(12)$ \\
\hline Minimize organizational corruption & $4.87(14)$ & $4.75(14)$ \\
\hline Acquire knowledge of ethical codes & $4.56(15)$ & $4.29(15.5)$ \\
\hline $\begin{array}{c}\text { *Become familiar with Western traditions in } \\
\text { moral philosophy and political thought }\end{array}$ & $4.19(16)$ & $4.29(15.5)$ \\
\hline
\end{tabular}

ethical in their behavior. Indeed, by the same two-thirds margin, respondents said that they do not believe students become more ethical persons. A majority of respondents, however, believe students who receive ethics instruction use that knowledge to resolve ethical dilemmas. ${ }^{3}$ Even larger majorities $(88 \%$ and more) believe students do not become "self-righteous" or "develop an attitude of being more ethical than others."

These findings, although soft in gauging actual outcomes of ethics education, are encouraging. While ethics instructors do not believe they turn students into moral exemplars or virtuous persons, they firmly believe their efforts have a positive impact that, in turn, benefits the public.

\section{Moving Forward, Standing Still, or Sliding Backwards?}

In their overview of ethics education in the 1990s, Catron and Denhardt $(1994,60)$ call for "further progress in developing a shared understanding of the goals of ethics education, greater training opportunities for faculty interested in teaching ethics, and greater coverage and better coordination of ethics in the curriculum." The survey results presented in this paper point to some success in achieving a shared understanding of the goals of ethics education, although it would be wide of the mark to conclude that there is a consensus.

These data also suggest recent progress in providing greater coverage and better coordination of ethics in graduate programs of study. Catron and Denhardt's $(1994,57)$ observation that "overall, coverage of ethics in public administration programs is increasing" is supported by the 1995 data. More ethics courses are taught in the mid-1990s than ever before and a small but growing number of schools are offering or developing formal "ethics-across-thecurriculum" programs. ${ }^{4}$

Progress in ethics education, especially for public service professionals, is noteworthy and welcomed. Still, much remains to be done, particularly in providing support for faculty training and development. Support for faculty ethics training can and should be provided by universities and various professional associations. The American Society for Public Administration (ASPA) sponsors ethics workshops and conferences from time-to-time. Moreover, ASPA typically convenes several ethics panels at its annual conference (Cooper 1994, 23-24). In 1989, ASPA also sponsored national thematic conference entitled "Ethics in Government: The Intricate Web." This event resulted in the publication of a major ethics text by Carol Lewis (1991). Additionally, ASPA has published source books by Mertins (1979) and Richter, Burke, and Doig (1990). There has also been some movement within ASPA to create an ethics section which, presumably, would benefit faculty who wish to develop expertise and knowledge in ethics pedagogy.

At the university level, two national conferences have been held in the 1990s to bring together faculty interested in ethics scholarship and teaching. The first conference was held in 1991 in Park City, Utah, while the second conference was held in 1995 in Tampa, Florida. Each conference was well attended, suggesting the need for such specialized events. Whether these efforts will become institutionalized or merely occasional happenings is difficult to predict.

Direct support for faculty ethics training and development by universities is limited and spotty, according to the 1995 survey data. When respondents were asked, "Does your department/program support training and faculty development efforts to 


\section{TABLE 3}

\section{Emphasis Placed on Conceptual Approaches to Ethics Education} Rank Ordered by Average Scores

\begin{tabular}{lcc}
\hline & $\begin{array}{c}\text { All Respondents } \\
(\mathrm{n}=93)\end{array}$ & $\begin{array}{c}\text { Ethics Instructors } \\
(\mathrm{n}=56)\end{array}$ \\
\hline Moral reasoning & $5.66(1)$ & $5.82(1)$ \\
Democratic thought & $5.20(2)$ & $5.19(2)$ \\
Citizenship & $5.16(3)$ & $5.05(3)$ \\
Professional codes of conduct & $4.67(4)$ & $4.53(6)$ \\
Virtue and character development & $4.65(5)$ & $4.79(4)$ \\
Regime values via constitutionalism & $4.59(6)$ & $4.72(5)$ \\
Utilitarianism & $4.26(7)$ & $4.34(7)$ \\
Principles such as the Golden Rule & $3.98(8)$ & $4.16(8)$ \\
Covenants & $3.65(9)$ & $3.69(9)$ \\
\hline
\end{tabular}

Cell values represent average scores on a scale of $1-7$, with $1=$ not emphasized and $7=$ emphasized very heavily. Numbers in parentheses represent rank order from high (1) to low (9).

improve ethics education?" a majority $(55 \%)$ said "no." Among the 60 respondents who said "yes," most $(87 \%)$ said their schools provided funds to attend ethics workshops or seminars; $68 \%$ said their schools provided verbal encouragement. These "bright" spots, however, are dulled some by the fact that only 10 respondents (less than $20 \%$ ) said their schools provided instructional release time for faculty development.

Finally, the demographic data reported earlier describing who teaches ethics courses raises racialgender-ethnic diversity questions. The survey found that fewer than one of every four ethics instructors is female and almost none are nonwhite. In this "age of diversity," it seems that an effort is needed to foster a more diverse instructors corps. This effort may not be easy, however, since it appears that most $(90 \%)$ of those who teach ethics courses are drawn to it by their personal interests. Other motives, according to the 1995 survey, included one's research interest $(55 \%)$, NASPAA requirements (23\%), and the request of the chair to teach an ethics course.

"The field of ethics education for public service," Catron and Denhardt $(1994,60)$ contend, "is healthier and more vibrant today than it has been in decades." Yet, the findings reported in this paper point strongly toward the view that there is much left to do. Ethics education, like administrative ethics as a field of study in general, remains an emergent enterprise (Cooper 1994). Perhaps the time is at hand to push the fast forward button lest the "new" ethics that Bok described languish and even disappear from America's campuses as did moral education. The stakes are too high to allow ethics education, whether directed at PA/A programs or future members of the political science academy, to fall into disrepair. The ethical challenges facing America in the next century, both in and outside of the academy, are likely to grow in number and complexity. America's institutions of higher learning can and must respond to these challenges.

\section{Notes}

*The author thanks the following persons for their assistance and guidance in conducting this research. Professors Guy Adams at the University of Missouri, April Hejka-Ekins at California State University-Stanislus, Dalton S. Lee at San Diego State University, and Vera Vogelsang-Coombs at Cleveland State University were kind enough to review early drafts of the questionnaire. Their criticisms aided immensely in the preparation of the final instrument. Mr. Travis Dorsey, an MPA candidate and a graduate research assistant in the Department of Government and International Affairs at the University of South Florida provided valuable research support. The author is also pleased to acknowledge the financial support of the Research and Creative Scholarship Grant Program of the University of South Florida. Thanks are also due to the NASPAA representatives who gave generously of their time to respond to the question-

\section{TABLE 4}

\section{Instructional Methods and Technologies Used in PA/A Ethics Instruction Rank Ordered by Average Scores}

\begin{tabular}{lcc}
\hline & $\begin{array}{c}\text { All Respondents } \\
(\mathrm{n}=90)\end{array}$ & $\begin{array}{c}\text { Ethics Instructors } \\
(\mathbf{n}=55)\end{array}$ \\
\hline Small group discussion & $6.00(1)$ & $5.98(1)$ \\
Case studies & $5.78(2)$ & $5.93(2)$ \\
Decision making scenarios & $5.26(3)$ & $4.98(4)$ \\
Research papers & $5.17(4)$ & $5.22(3)$ \\
Lectures & $4.77(5)$ & $4.67(5)$ \\
Role playing & $3.86(6)$ & $3.51(7)$ \\
Self assessments & $3.70(7)$ & $3.56(6)$ \\
Videos/movies & $3.45(8)$ & $3.30(8)$ \\
Guest speakers & $3.41(9)$ & $2.76(11)$ \\
Simulations & $3.37(10)$ & $2.92(10)$ \\
Fiction/movies & $3.09(11)$ & $3.08(9)$ \\
Biographies & $2.92(12)$ & $2.73(12)$ \\
Field studies & $2.75(13)$ & $2.53(13)$ \\
PC multimedia material & $1.91(14)$ & $1.73(14)$ \\
\hline Cell values represent average scores on a scale of 1-7, with $1=$ "rarely used" \\
and 7 = "extensively used" in the respondent's program of ethics instruction. \\
Numbers in parentheses represent rank order from high (1) to low (14).
\end{tabular}


naire. The author assumes sole responsibility for all errors of omission or commission.

1. Previous surveys report smaller sample sizes. Worthley and Grumet (1983) surveyed 71 NASPAA schools, with 31 responding. Hejka-Ekins (1988) reports findings based on a survey of 51 ethics instructors, although she surveyed all 210 NASPAA schools. Catron and Denhardt (1994) examined 39 self-study reports submitted to NASPAA for the years 1989-91.

2. For an assessment of various instructional methods, see Donald C. Menzel, "To Act Ethically ..." at http://www.cas.usf/ $\sim$ menzel/menzel/richweb.html

3. See Menzel (1997) for additional evidence that ethics education makes a difference.

4. Examples of "ethics-across-the-curriculum" programs are provided in Bowman and Menzel (1997).

\section{References}

Bok, Derek. 1990. Universities and the Future of America. Durham: Duke University Press.

Bowman, James S., and Donald C. Menzel. 1997. Teaching Ethics and Values in Public Administration: Innovations, Strategies, and Issues. Albany: State University of New York Press.

Catron, Bayard L., and Kathryn G. Denhardt. 1988. Ethics Education in Public Administration and Affairs, A monograph of the Working Group on Ethics Education. American Society for Public Administration.

-. 1994. "Ethics Education in Public Administration." In Handbook of Administrative Ethics, ed. Terry L. Cooper. New York: Marcel Dekker, Inc.

Cooper, Terry L. 1994. "The Emergence of Administrative Ethics." In Handbook of
Administrative Ethics, ed. Terry L. Cooper. New York: Marcel Dekker, Inc.

Dwivedi, O. P., and E. A. Engelbert. 1981. "Education and Training for Values and Ethics in the Public Service: An International Perspective." Public Personnel Management 10(Special Issue): 140-45.

Fleishman, Joel L. and Bruce L. Payne. 1980. Ethical Dilemmas and the Education of Policymakers. Hastings on Hudson, NY: The Hastings Center.

Hejka-Ekins, April. 1988. "Teaching Ethics in Public Administration." Public Administration Review 48(September/October): 88591.

Jennings, Bruce, James Lindemann Nelson, and Erik Parens. 1994. Values on Campus: Ethics and Values Perograms in the Undergraduate Curriculum. Briarcliff Manor, NY: The Hastings Center.

Lee, Dalton S., and Darrel Pugh. 1987. "Codes of Ethics, Education, and the Making of a Profession." Presented at the Annual Meeting of the Western Social Science Association.

. 1990. "The Difficulty with Ethics Education in Public Administration." Interna tional Joumal of Public Administration 13(January/March): 181-205.

Lewis, Carol W. 1991. The Ethics Challenge in Public Service. San Francisco: Jossey-Bass, Inc.

Menzel, Donald C. 1997. "Teaching Ethics and Values in Public Administration: Are We Making a Difference?" Public Administration Review 57(May/June): 224-30.

Mertins, Herman., ed. 1979. Professional Standards and Ethics: A Workbook for Public Administrators. Washington, DC: American Society for Public Administration.

Piper, Thomas R., Mary C. Gentile, and Sharon Daloz Parks. 1993. Can Ethics Be Taught? Boston: Harvard Business School.

Richter, William L., Frances Burke, and Jameson W. Doig., eds. 1990. Combating Comuption/Encouraging Ethics. Washing- ton, DC: American Society for Public Administration.

Rohr, John. 1976. "The Study of Ethics in the PA Curriculum." Public Administration Review 36(July/August): 398-406.

Thompson, Frank J., ed. 1993. Revitalizing State and Local Public Service. San Francisco: Jossey-Bass Publishers.

Worthley, John, and Barbara Grumet. 1983. "Ethics and Public Administration: Teaching What 'Can't Be Taught."' American Review of Public Administration 17 (Spring): 54-68.

\section{About the Author}

\section{Donald C. Menzel}

is a professor of public administration and political science in the Department of Government and International Affairs at the University of South Florida,

Tampa. His most recent publications include "Through the Ethical Looking Glass Darkly," published in Administration \& Society (1995), "The Ethical Environment of Local Government Managers," published in American Review of Public Administration (1995), The American County: Frontiers of Knowledge, an edited volume published by the University of Alabama Press (1996). His current research interests are ethics and values in the public administration academy and World Wide Web survey research methodology. 